\title{
PARAPLEGIA FOLLOWING TRANSURETHRAL SURGERY
}

\author{
Y. Desnoyers, ${ }^{*}$ L. Bisson, $\uparrow$ And A. Sindon +
}

The exacerbation of an unsuspected neurological disease, following anaesthesia, has been previously described. ${ }^{1-4}$ This report documents a case of post-operative paraplegia and discusses two plausible and possibly aetiological factors.

\section{Report of a CASE}

An 80-year-old patient admitted to the hospital with urinary retention presumably caused by prostatic neoplasia, was scheduled for transurethral prostatectomy and orchidectomy.

A recent 10-pound weight loss and symptoms compatible with chronic obstructive pulmonary disease were the only other significant matters elicited on questioning. Electrocardiography indicated left ventricular hypertrophy, although repeated blood-pressure readings never exceeded $120 / 70$. Hb was $11.3 \mathrm{~g}$, haematocrit 33.8 per cent and fasting blood sugar $92 \mathrm{mg}$ per cent. A BUN level of $39 \mathrm{mg}$ per cent (normal 7 to $20 \mathrm{mg}$ per cent) and a creatinine level of $1.8 \mathrm{mg}$ per cent (normal 0.9 to $1.4 \mathrm{mg}$ per cent) were thought to indicate chronic renal failure. Total acid phosphatases were high at 8.6 K.A. units, as were prostatic acid phosphatases at 5.3 K.A. units. The radiologist verbally reported a negative metastatic bone study: the final written report, however, was not consigned to the patient's chart before operation.

The operation was performed under spinal anaesthesia. An atraumatic lumbar puncture was performed with the patient in right lateral decubitus position. A 22-gauge needle was introduced in the fourth lumbar space; the spinal fluid was clear and dripped freely; $14 \mathrm{mg}$ of tetracaine 1 per cent solution in dextrose 10 per cent without epinephrine were then injected and analgesia to the T5 level was obtained with the patient in the dorsal decubitus position.

Sixty minutes after the beginning of operation the patient was in distress. His blood pressure had dropped to $80 / 50$ although there had been no significant blood loss; he was dyspnoeic and complained of nausea. He was immediately placed in the Fowler position, and the intravenous dextrose infusion was replaced by a 3 per cent saline solution. Furosemide and mephentermine were injected. Water intoxication was suspected and surgery was promptly terminated while oxygen was administered by mask.

Two and a half hours after the beginning of anaesthesia, the patient was able to move both legs on command. A blood sample drawn in the recovery room con-

${ }^{\circ}$ Y. Desnoyers, M.D., F.R.C.P.(C), Assistant Clinical Professor, University of Montreal.

†L. Bisson, M.D., F.R.C.P.(C), Assistant Clinical Professor, University of Montreal.

1A. Sindon, M.D., F.R.C.P.(C), Assistant Professor, University of Montreal, Department of Anaesthesia, Maisonneuve-Rosement Hospital, Montreal, Quebec, Canada. 
tained $3.4 \mathrm{mEq} / \mathrm{l}$ of potassium, $131 \mathrm{mEq} / \mathrm{l}$ of sodium and $93 \mathrm{mEq} / \mathrm{l}$ of chloride, notwithstanding the administration of a saline solution in the operating theatre. $\mathrm{Hb}$ was $7.8 \mathrm{~g}$ and Hct $23.8 \mathrm{per}$ cent. (The per-operative blood loss had been estimated at $300 \mathrm{ml}$.) These figures were felt to be compatible with water intoxication.

On the first post-operative day the patient had marked abdominal distension. On the second day he sat by his bedside and moved his legs, although he could not stand up. Hypaesthesia was present below the nipple line. Muscle strength was diminished in all segmentes of the lower limbs but more on the left side than on the right. Deep tendon reflexes were normal. Abdominal distension persisted.

On the third post-operative day, neurological examination revealed anaesthesia and radicular pain below the third thoracic segment. Vibrations were not perceived below this level and abdominal reflexes could not be elicited. Both lower limbs were flaccid with absent ankle jerks. Knee jerks were intact and rather brisk. Both plantar reflexes were extensor with limb withdrawal. The rectal sphincter was atonic. Rectal temperature was $100^{\circ} \mathrm{F}\left(37,6^{\circ} \mathrm{C}\right)$.

By that time a formal radiology report was received and indicated the possibility of a partial collapse of the third and fourth thoracic vertebral bodies. Additional films of the spine were made and a lumbar myelography was performed. These studies were strongly indicative of a T4 epidural metastatic lesion. The presumptive diagnosis by this time was metastatic peridural lesion with spinal cord compression. Surgical decompression was not recommended in view of the patient's advanced age, his weakened condition and the very poor prognosis.

The patient received standard supportive care and his neurological status remained stable, although some observers reported a partial return of pain perception and discrete recuperation of motor activity in the right leg. His general condition, however, gradually deteriorated and he died two months following operation.

\section{Discussron}

Due to the difficulty in obtaining a worthwhile history from an elderly and gravely ill patient, and chiefly because of haste in proceeding to surgery before adequately assessing the results of the initial radiological examination, spinal anaesthesia was administered to a patient who was on the verge of spinal cord compression by an epidural metastatic prostatic carcinoma.

The abrupt post-operative appearance of a spinal cord compression syndrome following lumbar puncture can be attributed to displacement of the tumor mass a doubtful event in this case - or to peri-medullary vascular engorgement. It seems that alterations in cerebrospinal fluid dynamics, rather than the actual injection of a spinal anaesthetic agent is responsible for these phenomena. ${ }^{1}$

Could water intoxication have been a contributory factor in this case? Experimentally, intravenous injection of hypotonic saline or distilled water causes a marked and prolonged rise of cerebrospinal fluid pressure and shift of extracellular water into brain cells. ${ }^{5}$

Swelling of spinal cord nerve cells in the water intoxication syndrome has not yet been described: but it is not inconceivable, and such a phenomenon could have 
been responsible in the present case for the sudden clinical manifestation of a previously silent lesion.

\section{SUMMARY}

We have presented a case of paraplegia following spinal anaesthesia administered for a transurethral prostatic resection. Further investigation revealed a metastatic peridural compressive lesion at the level of T4. We have discussed some of the contributory factors involved, chiefly the lumbar puncture (perimedullary vascular engorgement, alterations in C.S.F. dynamics) and the possible role of intra-operative water intoxication (swelling of spinal cord cells).

\section{RÉSUMÉ}

Nous avons présenté un cas de paraplégie survenue à le suite d'une anesthésie rachidienne administrée pour une résection transurétrale de la prostate. L'investigation subséquente a démontré qu’il s'agissait, en fait, d’une métastase épidurale thoracique faisant compression. Nous avons discuté de divers facteurs déclenchants attribuables soit à la ponction lombaire (congestion vasculaire régionale, modification de la dynamique du L.C.R.), soit à l'intoxication à l'eau (œedème des cellules médullaires) per-opératoire.

\section{REFERENCES}

1. VANDAM, L.D. \& Dripps, R.D. Exacerbation of pre-existing neurological disease after spinal anesthesia. N. Engl. J. Med. 255: 843-849 (1956).

2. Phillips, O.C., EBner, H., Nelson, A.T., \& Block, M.H. Neurologic complications following spinal anesthesia with lidocaine. Anesthesiology 30:284-289 (1969).

3. Greene, M.N. Neurological sequelae of spinal anesthesia. Anesthesiology 22: 682-696 (1961).

4. Lund, P.C. \& CwIK, J.C. Modern trends in spinal anesthesia. Canad. Anaesth. Soc. J. 15: 118-134. (1968)

5. Applied Physiology. Tenth Edition. Edited by Samson Wright's. London, Oxford University Press, p. 52 (1961). 